\title{
THE FATHERLESS FAMILY
}

\author{
By Helen Glenn Trson, \\ State Supervisor, Mother's Assistance Fund of Pennsylvania.
}

Before the movement for mothers' pension legislation spread over the United States after 1911, there were two general forms of administering relief to fatherless families. The first was through private agencies, many of which have for more than a decade realized that the only constructive solution of the poverty problem presented by the fatherless family is a regular allowance on which the widow can depend to free her from worry and overwork and enable her to give her children real home care. The other form of administering aid was through the public agency for outdoor relief. Under the old Poor Laws, meager allowances had always been granted to widows, but never on any adequate basis; nor had the public officials administering this relief formulated any policies as to standards of family life to be required in the families aided, nor defined the quality of service to the children that could reasonably be demanded from the mother.

While a few states have developed their mothers' pensions system simply through an extension and re-interpretation of the old outdoor relief laws, the general form of the new public administration of relief has been through the courts. This seemingly chance development was probably due to the fact that in a number of states the courts still have jurisdiction over dependent children and that one of the best-known Juvenile Court judges in the country was the first to make an effort to have the jurisdiction of this court extended over such dependent families. Then, too, there was the greatest distrust and dissatisfaction with the old outdoor relief agencies among those interested in public welfare, and it seemed to be the easiest solution to divorce them entirely from the new administration of this form of aid. The states that have recently passed mothers' pension legislation, however, have realized how unsatisfactory administration of relief through the court is apt to be, and recent mothers' pension laws-notably those of New York, Pennsylvania, Delaware, and New Jersey-have created an en- 
tirely new piece of administrative machinery based on the plan of county organization, but with state supervision or control. These efforts to separate this group of dependent families for special treatment reveal a new realization that the community as a whole is largely to blame for the ills that afflict individuals, and a growing conviction that from the point of view of self-interest alone, the state must assume greater responsibility for the welfare of its children. In 1909 the Royal Commission on the Poor Laws of England recommended unanimously that the old poor law machinery be abandoned and a new public assistance authority be created. This year, 1918, in the midst of England's most costly war, this plan has been actually carried out and the new plan comprehends all forms of relief and special provision for dependents and defectives. $^{1}$

Our new Mothers' Assistance legislation, haphazard and unstandardized though these efforts to meet the needs of fatherless families through public action have seemed, has nevertheless these significant effects: definite opportunity is offered to the state to discover the causes of the untimely deaths of the fathers, at the very time of their greatest usefulness to society, industry and the family; also, the chance is given to estimate the cost to the state of preventable deaths of the breadwinner and the loss entailed by the subsequent dependency of the helpless family. ${ }^{2}$ With these facts as a basis for further action mothers' pension legislation should soon be taken over as an integral part of the larger and more constructive plan for social insurance. ${ }^{3}$ Yet even under such a system of state organization a certain number of young fathers will continue to die untimely deaths, leaving their families unprotected by any form of insurance and in need of organized assistance.

When the average individual hears the term "widow" if he does not think of the fictitious person named to obstruct any economic reform, there instantly flashes into his mind a type picture of the "poor widow" of sentimentalism: a frail, hard-working devoted

1 Bruno Lasker, "The Death Blow to England's Poor Law," The Survey, Feb. 23, 1918, pp. 563-564.

${ }^{2}$ Report of Special Inquiry Relative to Dependent Families in Massachusetts Receiving Mothers' Aid, 1913-17, Senate No. 244, pp. 77-141.

'Final section of report on work of Mother's Assistance Fund in Pennsylvania, pamphlet of State Board of Education, in press. See also, Commons, J. R., and Andrews, J. B., "Principles of Labor Legislation," pp. 406-409. 
mother, bending over a wash-tub and surrounded by a large group of hungry children. While there are no more innocent and pitiful sufferers from our unorganized social system than the widow and orphan, social workers know that there are as many kinds of widows as there are kinds of women. At one end of the line is the capable mother who will make any sacrifice to keep her children with her and rear them in decency and comfort; at the other, the weak or vicious woman who will exploit, neglect or abandon her children on the slightest pretext.

For the purposes of this paper the family with adequate financial resources is not considered; nor is the one where deterioration in the values of family life (whether due to environmental causes or individual defect) has compelled the breaking up of the family to save the individuals that compose it. The following discussion is limited to those fatherless families, where, with adequate income, the children bid fair to become normal useful citizens under their mother's care.

Whether relief to a fatherless family is administered through a public or a private medium, there are certain prerequisites of assistance which all agencies endeavoring to follow modern methods of social service have established. Investigation should not stopas all too frequently in the past,- - with the proof of the fact and degree of need of the family. A full consideration of the financial resources available in the way of help from relatives, property or money owned by the widow, her own or her children's ability to contribute without harm to the support of the family is of course essential. But the value of the family life measured through a consideration of the mother's mental, moral, and physical fitness to bring up her children must also be determined by investigation. Assistance should not be given in families where the mother is mentally unsound or defective, morally weak, or physically unable to give the children decent home care. Finally, investigation should show the basis of a plan for the future welfare of the family. After the decision to grant assistance is made, the social case treatment of the family should be organized about this plan.

In any family the elements of normal life are disrupted by the death of the breadwinner. His loss is more than the loss of a pay envelope. At this stage of the social and economic development of woman the removal of the father of the family is apt to have a 
very serious effect upon the family's solidarity. His loss is felt in the making of plans for the spending of the income effectively as well as in the loss of the income itself. There is great need of his discipline and advice in the training of the children, especially in the case of growing boys. In certain foreign groups particularly, where the status of woman is regarded as so much lower than that of man, it seems almost impossible for a mother no matter how devoted and earnest, to control and guide her restless, adolescent son. Often, too, the father has been the one to attend to such business details as the payment of rent and insurance dues, the one to arrange for necessary medical care for the children. The father also gives the family a certain social and economic status in the community through his relation to labor organizations, employers, and politicians. His advice at the time the children begin to enter industry and to choose occupations for themselves is usually sorely needed. To supply all these weaknesses in the family life is the task of the social worker who administers relief to the family and supervises their welfare.

In many ways the fatherless family offers the ideal group for a demonstration of the value of social case treatment provided that the assistance given is adequately and wisely planned. The Home Service of the Red Cross bases its strong claim to serve the families of soldiers and sailors on similar grounds. ${ }^{4}$ A growing family of normal children offers every opportunity for constructive study and guidance. The mother is free from the strain of child bearing and as the children grow older can give more attention to the development of family life. The fact that the income is adequate and steady and not open to fluctuations due to unemployment, illness of the breadwinner, or personal weaknesses on his part such as drunkenness and brutality, enables the mother to gain habits of foresight and thrift that she has perhaps never been able to develop before. A study of the social records of families adequately assisted and well supervised shows that in many cases a rise in the standard of living of the family has actually been achieved. Certainly there can be no more satisfying result in social case treatment than the "graduation" of a widow's family into complete independence, with fuller social contacts, good educational grounding, and a well-rounded family life.

After investigation has established the fact and degree of need

‘A. R. C. 201 "Manual of Home Service." Second edition, pp. 13-46. 
of the family, discovered all available and legitimate resources to meet that need, and found that the mother is mentally, morally, and physically fit to perform her normal duties to her children, the first step in the plan for future supervision is the consideration of a sound financial basis on which the family should be maintained. Unfortunately it is still true that most fatherless families do not come to the attention of any social agencies, public or private, until some time after the death of the man. This period is almost sure to be one of family deterioration. The strain of the father's illness and death, the pressing need of the necessities of life, the demands on the mother's time and strength from her effort to support the family and maintain the home all tend to involve her in difficulties that she could not surmount alone. Through the widow's short sightedness or total ignorance of the world of business, the insurance money slips in a few weeks through her fingers. Dozens of instances can be described by social workers where a designing "friend" of the husband has taken advantage of the widow's ignorance to appropriate the larger part of the small lump of insurance, or where well-meaning neighbors or friends have given her just the kind of advice most certain to deplete her little fund. The usual bad investment of this sort is either the buying of a home under a heavy mortgage in a congested or neglected neighborhood, chosen with no consideration of sanitation, neighborhood conditions, or nearness to work and school; or the expenditure of the few hundred dollars for stock for a little store. In hundreds of such instances the stock has soon been sold; there is of course no capital to replenish it; and finally the little store cleses and the family's small reserve fund vanishes with it.

It is surprising to social workers to find how frequently women have not been allowed by their husbands to handle money even for the household needs. Obviously it takes a certain amount of foresight to save ahead for the rent and insurance and even more to realize that furniture or other household necessities bought on the installment plan are not a good investment. Before working out a budget of living expenses for the family, the case worker usually must spend some days in discovering what the family's liabilities are, and in straightening out a tangle of unpaid bills, lapsed insurance policies, and installment charges.

After the existing economic resources of the family are dis- 
covered, the next consideration involves deciding which of these are legitimate assets that can be counted on for the future, and which part of the income should be cut off or decreased for the wellbeing of the family. In many states the law determines the maximum amount of property and money a widow may have and still be eligible for assistance. There is some difference of opinion and legal provision on this question, varying, for example, from the law in Illinois where a mother is disqualified for assistance if she possesses any property and money, to California, where a maximum of five hundred dollars in cash and a thousand dollars in property is allowed. The consensus of opinion seems to be that some equity in property, provided it is the widow's own home, tends to a'dd to the self-respect and thrift of the family and to keep them in the neighborhood and town where they have become established and where all their natural social contacts have been made. The sacrifice of a home to most people brings great discouragement and the feeling of loss of social standing. Then too, many instances prove that it would have been actually cheaper to assist a mother who owns her home, provided the home was suitable to the family's needs and not deteriorating in value, than to insist that she sacrifice it at a forced sale only to become a heavier charge on the community later.

In the matter of money in the bank, since for the sake of economy in the distribution of available funds the amount of the menthly grant must be based on a necessity standard of living, a little surplus is invaluable for meeting emergencies of sickness and accident that constantly arise in a family of young children. This small reserve sum, however, should never be regarded as a source of income to be drained gradually through an inadequate grant; and the understanding with the mother should be that it is only for emergency needs. Yet there is no doubt that its possession adds to her feeling of independence and security from want.

In considering the question of relatives as a source of income the tendency seems to be for public agencies to take a different attitude from that held by private societies. If relief is given by a public agency the attitude of the community usually is that a widow's relatives like other citizens of the state are contributing to her need through taxes and, except where the law holds them legally responsible for her support, that they have a right to claim exemption from that responsibility. There are of course many cases in which rela- 
tives, not responsible under the law, have willingly shared with a public agency a part of the economic burden of the family. The insistence of private agencies on the fullest possible aid from relatives is founded on the belief that only through the enforced sense of mutual responsibility can family solidarity be maintained, and that loyalty to one's own kin is a human value which must not be allowed to go to waste. Whether such human values are actually enhanced by insistence on financial help from relatives already struggling to make ends meet is open to question. ${ }^{5}$ There is no question, however, that the financial and social status of the relatives should be determined and their help, particularly in other than financial ways, enlisted for the family.

One of the first methods of increasing income to which the needy widow turns is the keeping of men lodgers. Through bitter experience over many years and with a large number of families, social workers are unqualified in their disapproval of this method of adding to the income. Aside from the fact that the presence of any stranger has a disrupting effect upon the family life there are many general considerations that render the policy a bad one. The effect of the men's influence on the growing boys is often bad, the difficulty of making decent sleeping arrangements in a small house, and the actual danger of physical violence to the woman or the little girls in the family must be considered. Quite often companionship and propinquity lead to intimacy; and illegitimate children make the family problems more difficult. Even close supervision cannot ward off these dangers. In the case record of a family which has been under the supervision of one of the best private agencies in the country since 1911 we find the following significant entries:

10/2/11, Widow a particularly sweet, appealing person. Children clever and most attractive. On account of high type of woman it seemed safe to allow her to keep her three boarders. They are a good class of men, interested in the children and helpful with them. When the children need treatment, Nick, one of the boarders, takes them to the hospital.

$10 / 20 / 13$, State Dispensary reports that they suspect pregnancy. This was confirmed later by a private physician.

$2 / 17 / 14$, Henry, 12, removed by Juvenile Court.

$5 / 2 / 14$, Tony, 10, removed by Juvenile Court.

$7 / 7 / 16$, Polney, 10, removed by Juvenile Court.

5See discussion "A Misplaced Burden," Charities and the Commons, Oct. 13, 1906, p. 118. See also I. Rubinow, "Social Insurance," pp. 313-315. 
According to the other entries in the record this family shows a slow but steady deterioration. If a firm stand on the lodger question had been taken in the beginning, immediately after the husband's death, it is possible that the breakdown might not have occurred.

Another usual source of income for the family and one to be considered most carefully is the mother's own earnings. In judging whether or not a mother receiving assistance should contribute to the family's support, exactly the same considerations should hold that govern any mother's decision about work outside the home. That is, the question of whether she should add at all to the family income and to what extent, should be decided by a study of the age and number of the children, the condition of the mother's health, the provision of care for the children during her absence, and also her own inclination, capacity and past habits. No intelligent plan about the mother's work can be made unless the amount which she adds to the family budget be regarded as of secondary importance to these other determining questions.

Study of the industrial conditions of working mothers has shown that the large majority are employed in unskilled, unstandardized work at the lowest wages and for the longest hours. ${ }^{6}$ Office cleaning seems to be the work usually condemned by social workers for the mother of young children on the ground that it is extremely fatiguing and comes at just the time of day, morning and evening, when she is most needed by the children. Of course, a busy mother, who works at night, finds it very difficult to get the proper amount of sleep during the day and at the same time perform her household duties and give her children the proper care. There is also a frequent temptation to the fatigued mother in going through the streets in the cold and dark to take a stimulant or make undesirable acquaintances. The fact that even trained social workers are sometimes strangely blind to the dangers involved in permitting the mother to do this kind of work is shown in the following extracts from the case record of an assisted family:

Mother with 6 children, ranging from 15 months to $9 \frac{1}{2}$ years.

6/5/15 M. working at K. \& B. Dept. store 4 hours every evening. Receives $\$ 1$ a day.

- Katherine Anthony, "West Side Studies: Mothers Who Must Earn." R. S. F. Survey Associates, June, 1914, p. 153. 
$1 / 18 / 16$, Visitor found a man sitting at the kitchen table in the evening. Said he lodged in the same house and watched the children evenings while the mother worked.

$3 / 29 / 16$, Petition filed in Juvenile Court. Children neglected. Mother illegitimately pregnant.

While other factors than the mother's night work probably contributed to the deterioration of this family it is clear from the entries in the record that it was the chief cause. If it is necessary and desirable that the mother supplement the income, the consensus of opinion seems to be that sewing, fine laundry, or the care of other dependent children are more desirable than the usual forms of work because these occupations do not demand fixed hours of labor, and can be carried on at home while she is attending to her family's needs.

The question of the contribution of working children to the family income is one that can be summarized briefly. In order to increase the family income, no child should be forced into work prematurely, or under conditions that jeopardize its health or future development. It is equally true that a child should not be permitted to contribute more than a reasonable amount of its wages to the support of the family and should not be made to feel that the family is dependent on its earnings to an undue degree.

After the family resources in property and money, financial help from relatives, and ways in which the mother and children may safely add to the family income are considered, the question of the budget on which the family may be expected to maintain a good family standard must be decided. There is no doubt that continuous and adequate relief can be used as a lever to lift family standards of living, and that it is not money aid in itself but the method of administering it that may do harm. One of the arguments against public assistance is that it lacks the elasticity of private relief and cannot easily be adapted to the changing needs of the family. But this is equally true of the weekly wage of the father, and the average family must plan on a fixed sum. The feeling of security which a fixed monthly or weekly allowance gives to a widow enables her to develop those qualities of foresight and thrift by which she may plan ahead for the winter's coal or the next month's rent.

So much scientific and detailed work has been done on budget planning for assisted families that it is unnecessary to describe it here. 
The one basic principle, however, is that the amount granted, if expended with reasonable care, must be adequate to ensure maintenance of health, working efficiency, and a good standard of family life.

It is no exaggeration to say that there is hardly a family applying for assistance in which at least one member does not show signs of malnutrition or disease. In the mothers the strain of child bearing, overwork, worry and enforced neglect of the simplest rules of hygiene have often resulted in chronic functional disorders or in conditions requiring surgical care; varicose veins, gynaecological and digestive disorders, flat feet and cardiac trouble are ailments common to these mothers. Among the children, disorders due to neglect and under-nourishment are prevalent and there is great need for the medical treatment of skin diseases, throat conditions, anemia, eye strain, and other disorders that may result in serious retardation in school and later in industrial efficiency. To meet these health needs the aid of private physicians, hospitals, convalescent homes and sanatoriums must be enlisted.

In outlining a plan for supervision for a fatherless family it is well to decide what changes in the family life should be made at once. Even if emergency aid only is given for a few days, it is often wise to withhold regular assistance until a child who has been illegally employed is back in school, the man lodger eliminated, and in some cases until a member of the family in urgent need of medical care is actually under treatment. When regular assistance begins, the mother's hours of work should be changed at once to meet the plan for proper home care of the children. Other changes, such as the improvement in the school records of the children, training the mother in budget keeping, and securing dental care for the family, may require months of regular visiting and patient effort.

In this attempt to ensure the progress and welfare of the family it is perhaps unnecessary to say that the advice and help of clergymen, school teachers, former employers and relatives are needed. Other social agencies can often render the special kind of service that is required to fit some particular need. A housing association may be consulted about a sanitary home in a good neighborhood; a visiting nurse called in if there is sickness in the family; a vocational guidance bureau requested to advise the children as they approach working age; the interest of a settlement or commun- 
ity center enlisted to secure recreation and wider social contacts for the family.

The reading of a considerable number of records of assisted families in several cities that had been under the care of either a public or private agency showed that there are still valuable opportunities in supervision that have hardly been touched. In many cases the influence of the personality and ideals of the dead father is a vital factor in the family life, yet only in isolated instances was there any reference to his plans and ambitions for his children. While many records show an attempt to regulate the hours and working conditions of the mother, there were practically no instances where she was offered the opportunity of training for more highly skilled and better paid work. In view of the fact that she is usually quite young and will often be obliged to contribute to her children's support for many years to come, it would seem a wise economy to consider this possibility of increasing her earning power. While the children are often put in the way of obtaining healthful pleasures and forming helpful friendships, the same need in the life of the mother is not considered. In one agency a special effort was made to encourage the mothers of assisted families to join mothers' clubs, attend night school, and seek some social connection outside the home. A study of one hundred records of this agency showed that at the time the grant was made eighty-five of the one hundred mothers were highly nervous and depressed. After the families had been supervised and aided for a year only fifteen of the eighty-five had failed to become cheerful and self-controlled. Certainly this remarkable change must have been due to some extent to the social contacts the mothers had made.

Assistance and supervision of fatherless families under existing community organization can only be rendered successfully by trained social workers; but in most communities there is not only no developed social consciousness, but no one who knows the technique of social service. It is clear that a full measure of state supervision and state aid is badly needed in all such communities. A social reform measure, introducing an intricate new mechanism, but left to the isolated local community to administer, is doomed to inefficiency. Payment for adequate investigation and supervision in most communities must be made out of state funds, and be under state control if the work is to be successful. 
It has been repeatedly pointed out that the only just way to solve the problem of the widow and orphan is to reduce their number by seeking to keep the wage-earner alive. The really preventive remedy here is social insurance. The insurance principle makes premature deaths expensive and so tends to reduce their number. The insurance method is also effective in making it possible for the wage-earner to provide for his own wife and children in case of his death, without leaving them to be cared for by any relief agency, private or public.

The theory and even the practice of the mothers' pension work are more closely identified with public relief than with the preventive measure of insurance. It provides state grants for dependent families, on proof of destitution, for the purpose of enforcing a measure of state guardianship over the health and education of its wards. As has been shown, emphasis is placed on moral considerations as well as financial need. Where it has been successfully administered it represents a new and fine piece of public machinery, made effective by its use of the approved methods of private agencies. With the thorough-going social reform that is likely to follow the war, and which is in fact already under way in England, our antiquated poor laws will be done away with. The unemployed, the old, the sick, the invalid, and the widow and orphan as well, may soon be cared for democratically by social, or contributory, insurance. Yet even under such an advanced social organization there will still be a residuum of individuals and families requiring social case treatment. It is to be hoped that out of America's significant new experiment in public charity-the mother's assistance workmay ultimately come a superior piece of public relief machinery replacing the old and discarded outdoor relief, and embodying all the principles of case diagnosis and treatment that have been worked out so carefully by the private agencies in the past. 